\title{
SUPPLY OF PRIMARY PHYSICIANS AND THEIR WORKLOAD IN THE PRIMARY HEALTH CARE INSTITUTIONS AND BY DISTRICTS IN THE REPUBLIC OF SERBIA
}

\section{OBEZBEĐENOST IZABRANIM LEKARIMA I NJIHOVA OPTEREĆENOST U USTANOVAMA PRIMARNE ZDRAVSTVENE ZAŠTITE I PO OKRUZIMA U REPUBLICI SRBIJI}

\section{Zdenka Janković ${ }^{1}$, Anđelija Nešković ${ }^{1}$}

\section{SUMMARY}

Introduction/Aim: Determination and planning of a sufficient number of primary physicians is a prerequisite for high-quality primary health care. The aim of this paper was to determine the supply of primary physicians in the primary health care institutions and by districs in the Republic of Serbia in 2017, to analyze their workload and to compare the obtained values with the prescribed supply and workload.

Methods: A secondary analysis of the supply and the workload of primary physicians in the health care services for adults, small and pre-school children, school children and women for 2017 was carried out in the public primary health care institutions (health centers and institutions) in the Republic of Serbia. The assessment of the supply and the workload of the primary physicians was made in relation to the values prescribed by the legislation.

Results: In 2017, the supply of primary physicians in Serbia in the health care service for adults was higher than the prescribed one by $2 \%$ (1564 inhabitants per a physician), and higher by $13 \%$ (735 children per a physician) in the health care service for small and preschool children. There was a shortage of physicians, i.e. the supply of physicians in the health care service for women was lower than the prescribed one by $3 \%$ (6706 women per a physician) and by $9 \%$ (1630 school children per a physician) for the health care of school children. The supply that was more unfavorable than the prescribed one existed in 13 districts in the health care services for adults and women, in 7 districts in the health care service for small and pre-school children, and in 17 districts in the health care service for school children. The average daily workload of physicians was higher than the prescribed execution measures in the health care services for adults $(36,5)$ and for children $(30,6)$, and it was lower in the health care service for women $(26,2)$, but it was at the prescribed level in the health care service for school children $(30,0)$. The workload of physicians (expressed as the average number of visits per a physician) was higher

\section{SAŽETAK}

Uvod/Cilj: Određivanje i planiranje dovoljnog broja izabranih lekara je preduslov za kvalitetnu primarnu zaštitu. Cilj rada je bio da se utvrdi obezbeđenost izabranim lekarima po ustanovama primarne zaštite i okruzima u Republici Srbiji u 2017. godini, kao i da se analizira njihova opterećenost.

Metod rada: Izvršena je sekundarna analiza podataka o obezbeđenosti i opterećenosti izabranih lekara u službama za zdravstvenu zaštitu odraslih, male i predškolske dece, školske dece i žena, u zdravstvenim ustanovama primarne zaštite (domovi zdravlja i zavodi) koje su u javnoj svojini u Republici Srbiji u 2017. godini. Ocena obezbeđenosti i opterećenosti izabranih lekara izvršena je u odnosu na vrednosti propisane zakonskom regulativom.

Rezultati: U 2017. godini u Srbiji je obezbeđenost izabranim lekarima bila veća od propisane u službi za zdravstvenu zaštitu odraslih za 2\% (1564 stanovnika po lekaru), a u službi za zdravstvenu zaštitu male i predškolske dece za 13\% (735 dece po lekaru). U službi za zdravstvenu zaštitu žena obezbeđenost lekarima je bila manja za 3\% (6706 žena po lekaru), a u službi za zdravstvenu zaštitu školske dece za 9\% (1630 školske dece po lekaru) u odnosu od propisanu. Obezbeđenost lekarima je manja od propisane u 13 okruga u službi za zdravstvenu zaštitu odraslih i zdravstvenu zaštitu žena, u 7 okruga u službi za zdravstvenu zaštitu male i predškolske dece i u 17 okruga u službi za zdravstvenu zaštitu školske dece. Prosečna dnevna opterećenost lekara (iskazana kao prosečan broj poseta po izabranom lekaru) je veća od propisanih mera izvršenja u službama za zaštitu odraslih $(36,5)$ i dece $(30,6)$, a manja u službi za zdravstvenu zaštitu žena $(26,2)$, dok je u službi za zdravstvenu zaštitu školske dece $(30,0)$ na nivou propisane. Opterećenost lekara je veća od propisane u 17 okruga u službi za zdravstvenu zaštitu odraslih, 10 okruga u službi za zdravstvenu zaštitu male i predškolske dece, 13 okruga u službi za zdravstvenu zaštitu školske dece i u 6 okruga u službi za zdravstvenu zaštitu žena.

\footnotetext{
${ }^{1}$ Institute of Public Health of Belgrade, Serbia (Gradski zavod za javno zdravlje Beograd, Srbija)
} 
than the prescribed one in 17 districts in the health service for adults, in 10 districts in the health care service for small and pre-school children, in 13 districts in the health care service for school children, in 6 districts in the health care service for women.

Conclusion: There are great differences in the supply and workload of primary physicians by districts. It is necessary to ensure adequate human resource planning that takes into account both of these parameters and which will contribute to the advancement of personnel policies to reduce district disparities.

Keywords: district, primary health care, primary physicians, supply, workload

\section{Uvod}

Istraživanja su pokazala da zemlje sa dobro razvijenom primarnom zdravstvenom zaštitom imaju bolje ishode po zdravlje stanovništva, manje su socio-ekonomske nejednakosti u samoproceni zdravlja, kao i stope nepotrebnih hospitalizacija $(1,2)$.

U Srbiji građani primarnu zdravstvenu zaštitu ostvaruju preko izabranog lekara. Izabrani lekar je: doktor medicine ili doktor medicine specijalista za oblast opšte medicine, odnosno specijalista medicine rada; doktor medicine specijalista pedijatrije; i doktor medicine specijalista ginekologije (3).

Određivanje i planiranje dovoljnog broja izabranih lekara je preduslov za kvalitetnu primarnu zdravstvenu zaštitu. Poznato je da nedovoljan broj lekara dovodi do nemogućnosti da se zadovolje zdravstvene potrebe korisnika, stvaranja lista čekanja, razvijanja nejednakosti u zdravlju, kao i nezadovoljstva korisnika, a kod davalaca zdravstvenih usluga prouzrokuje preopterećenost i nezadovoljstvo poslom. S druge strane, neadekvatno veliki broj lekara dovodi do povećanja troškova u zdravstvenom sistemu (4-6).

Nedostatak zdravstvenih radnika i njihova neravnomerna zaposlenost po regionima, beleži se u svim zemljama sveta bez obzira na njihov društveno-ekonomski razvoj (7). Upravo zbog navedenog, cilj ovog rada je da se utvrdi obezbeđenost i opterećenost izabranih lekara u ustanovama primarne zdravstvene zaštite i po okruzima u Republici Srbiji u 2017. godini.

\section{Metode}

Izvršena je sekundarna analiza podataka o broju izabranih lekara, broju stanovnika i obimu rada izabranih lekara za 2017. godinu u zdravstvenim ustanovama primarne zdravstvene zaštite (domovima zdravlja i zavodima)
Zaključak: Postoje velike razlike po okruzima u obezbeđenosti i u opterećenosti izabranih lekara. Neophodno je obezbediti adekvatno planiranje humanih resursa koje će uzeti u obzir oba navedena parametra i koje će doprineti unapređenju kadrovske politike u cilju smanjivanja razlika između okruga.

Ključne reči: primarna zdravstvena zaštita, izabrani lekari, obezbeđenost, opterećenost

koje su u državnoj svojini u Republici Srbiji (bez zdravstvenih ustanova sa područja Kosova i Metohije).

Kao izvor podataka o broju izabranih lekara i obavljenim posetama, korišćen je Zdravstveno-statistički godišnjak za 2017. godinu Instituta za javno zdravlje Srbije (IZJZ) „Dr Milan Jovanović-Batut“ (8). Iz Zdravstveno-statističkog godišnjaka Republičkog zavoda za statistiku za 2017. godinu preuzeti su podaci o broju i starosnoj strukturi stanovnika (8). Procenjeni broj stanovnika grupisan je prema starosnim grupama u skladu sa organizacijom primarne zdravstvene zaštite: deca predškolskog uzrasta od 0 do navršenih 6 godina; deca školskog uzrasta od 7 do 19 godina; odrasli od 20 i više godina; i, žene od 15 i više godina.

U analizi su posmatrane sledeće četiri organizacione jedinice, odnosno službe za: zdravstvenu zaštitu odraslih, zdravs tve nu zaštitu male i predškolske dece, zdravstvenu zaštitu školske dece i zdravstvenu zaštitu žena.

Broj izabranih lekara u službi obuhvata doktore medicine i doktore medicine specijaliste koji rade u toj službi, ali ne i lekare na specijalizaciji. Za izračunavanje opterećenosti izabranih lekara korišćeni su podaci o ostvarenim posetama u ordinaciji lekara, kao i obavljeni sistematski i kontrolni pregledi, dok kućne posete nisu uračunate. Podaci o obavljenim sistematskim pregledima školske dece i pregledima koje su obavili izabrani ginekolozi u savetovalištima za trudnice i za planiranje porodice su dobijeni na zahtev od Instituta za javno zdravlje Srbije „Dr Milan JovanovićBatut", s obzirom da navedeni podaci nisu publikovani u Zdravstveno-statističkom godišnjaku.

Obezbeđenost izabranim lekarima izračunata je kao odnos broja stanovnika određenog uzrasta i broja izabranih lekara. Ona je analizirana u odnosu na nivo obezbeđenosti 
koja je propisana zakonskom regulativom, i to: 1600 odraslih stanovnika u službi opšte medicine po jednom doktoru medicine ili doktoru medicine specijalisti, 850 dece uzrasta 0-6 godina u službi za zdravstvenu zaštitu male i predškolske dece po jednom lekaru specijalisti pedijatrije, 1500 dece uzrasta 7-19 godina u službi za zdravstvenu zaštitu školske dece po jednom lekaru specijalisti pedijatrije ili doktoru medicine i 6500 žena starosti 15 i više godina u službi za zdravstvenu zaštitu žena po jednom lekaru specijalisti ginekologije (9).

Dnevno opterećenje izabranih lekara dobijeno je deljenjem ukupnog broja poseta sa ukupnim brojem izabranih lekara (bez lekara na specijalizaciji) u navedenim službama i brojem radnih dana na godišnjem nivou (210). Ocena opterećenosti izabranih lekara analizirana je $u$ odnosu na mere izvršenja propisane zakonskom regulativom (u službama za zdravstvenu zaštitu male i predškolske dece, zdravstvenu zaštitu školske dece i zdravstvenu zaštitu žena: 6300 pregleda po lekaru godišnje ili 30 pregleda dnevno, a u službi za zdravstvenu zaštitu odraslih: 7350 pregleda godišnje ili 35 pregleda dnevno) (9).

\section{Rezultati}

U Srbiji je u 2017. godini živelo 7.020 .858 stanovnika, od kojih je bilo: $458.199(6.5 \%)$ dece uzrasta 0-6 godina, $901.152(12.8 \%)$ dece uzrasta $7-19$ godina, $i$ 5.666.507 (80.7\%) odraslih (20+ godina).

Stanovnici Srbije su u 2017. godini ostvarili blizu 38 miliona poseta kod 5261 izabranog lekara u domovima zdravlja i zavodima koji obavljaju zdravstvenu delatnost na primarnom nivou. U proseku na 100.000 stanovnika, zdravstvenu zaštitu je obezbeđivalo 75 izabranih lekara.

Najveći broj izabranih lekara (3621 ili $68,9 \%$ od ukupnog broja lekara) je radilo u službi za zdravstvenu zaštitu odraslih (Grafikon 1).

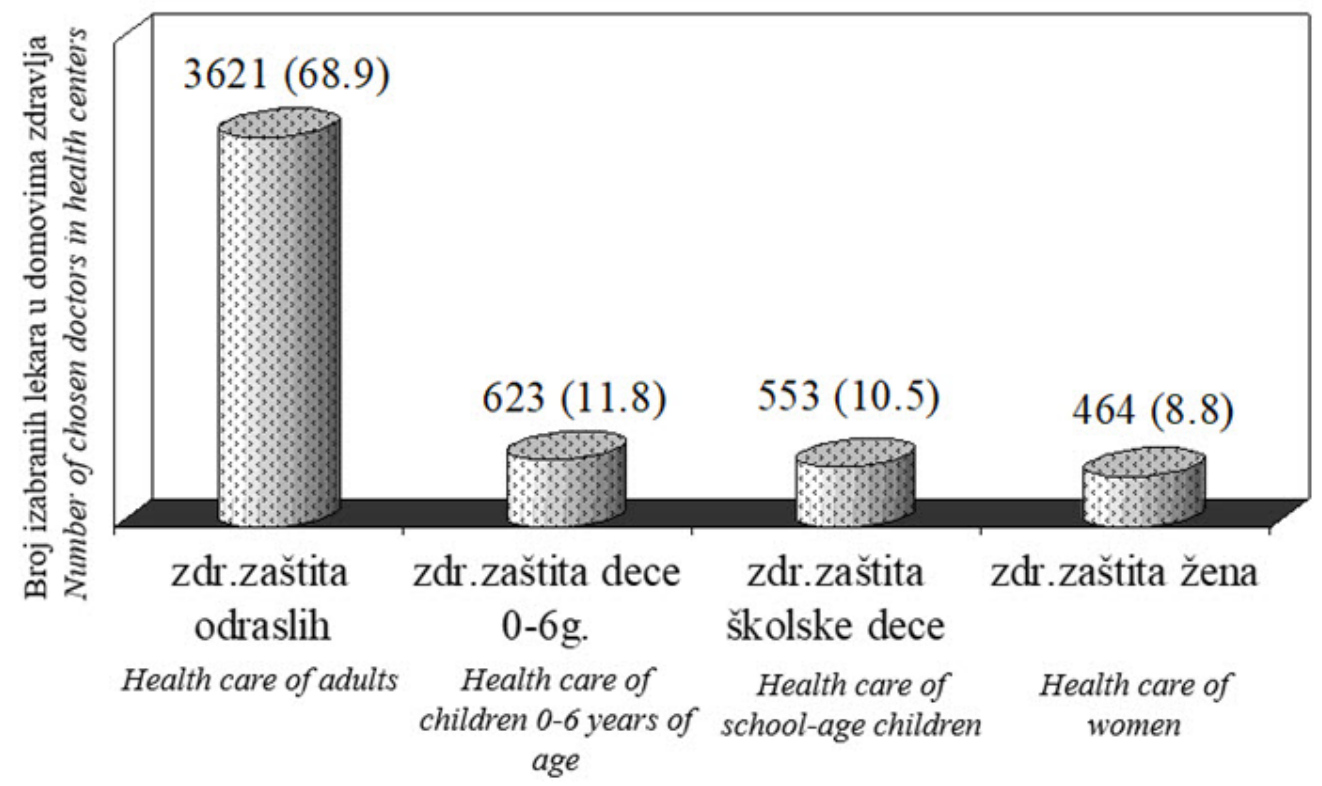

Grafikon 1. Broj izabranih lekara u domovima zdravlja i zavodima na primarnom nivou u Srbiji po različitim službama, kao i njihovo procentualno učešće među svim izabranim lekarima, Srbija, 2017. godina

Figure 1. Number of primary doctors in health centers and institutions at primary level in Serbia by different services, as well as their percentage participation among all selected doctors, Serbia, 2017

U odnosu na ukupan broj poseta u 2017, najveće učešće imaju posete izabranom lekaru u službi za zdravstvenu zaštitu odraslih, oko 3/4 (oko 27,7 miliona poseta), a zatim slede posete male i predškolske dece (oko 4,5 mil- iona ili $10,6 \%$ od svih poseta), školske dece (oko 3,5 miliona ili 9,2\%) i posete izabranom ginekologu u službi za zdravstvenu zaštitu žena, oko 2,5 miliona ili 6,7\% (Grafikon 2). 


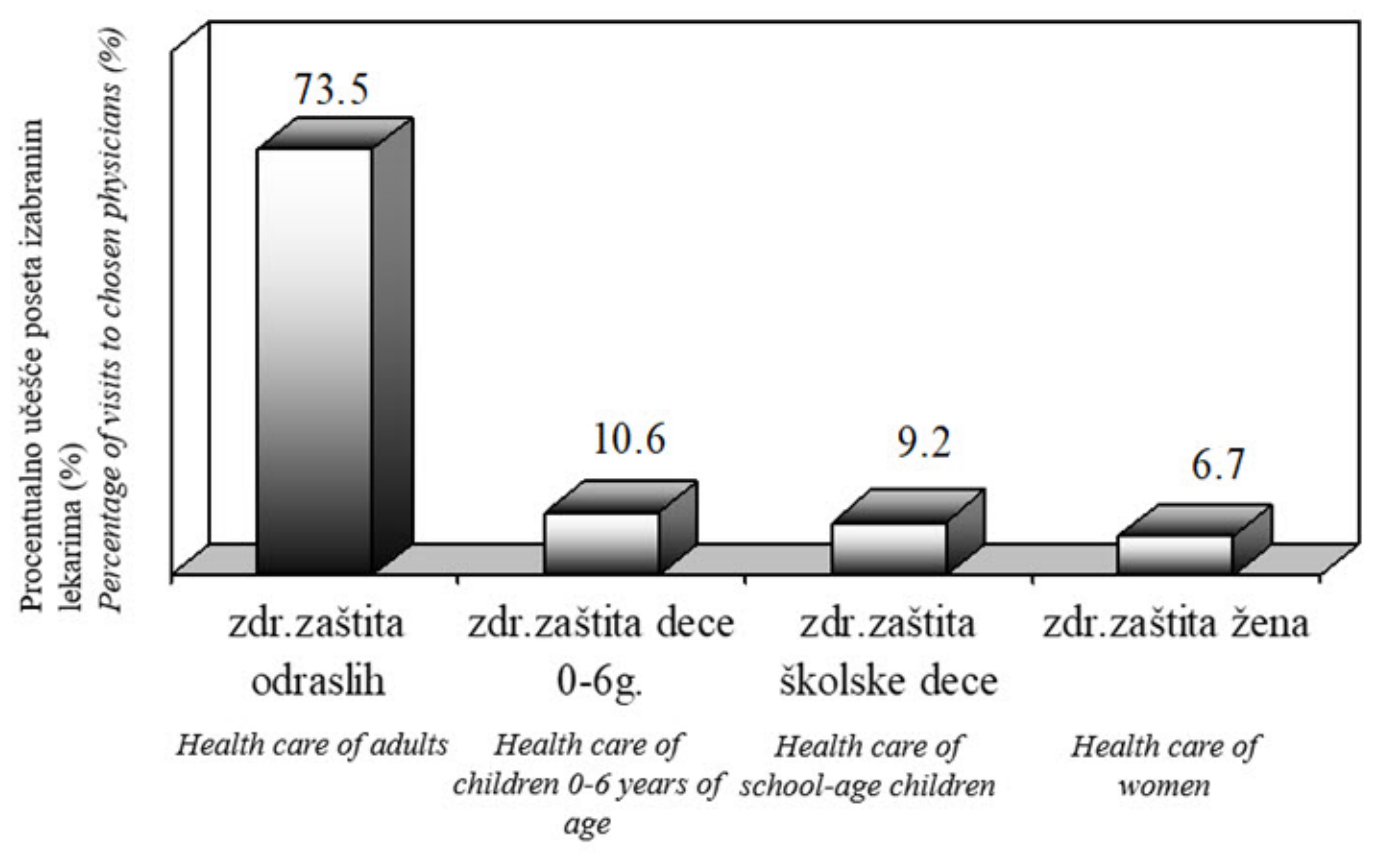

Grafikon 2. Procentualno učešće poseta izabranim lekarima u određenim zdravstvenim službama u zdravstvenim ustanovama na primarnom nivou u u odnosu na ukupan broj poseta izabranim lekarima, Srbija, 2017. godina

Figure 2. Percentage of visits to primary physicians in certain health services in health facilities at primary level in relation to the total number of visits to selected physicians,

Serbia, 2017

\section{Služba za zdravstvenu zaštitu odraslih stanovnika}

U 2017. godini u zdravstvenim ustanovama primarne zdravstvene zaštite u Srbiji, 3621 izabrani lekar (1862 lekara opšte medicine i 1759 lekara specijalista opšte medicine) u službi za zdravstvenu zaštitu odraslih je pružao zdravstvenu zaštitu za 5.661.507 odraslih stanovnika. To znači da je u proseku, svaki izabrani lekar u ovoj službi obezbeđivao zdravstvenu zaštitu za 1564 stanovnika. Obezbeđenost lekarskim kadrom bila je za 2\% bolja od one koju je propisalo Ministarstvo zdravlja (1600 odraslih stanovnika po doktoru medicine i doktoru medicine specijalisti opšte medicine) (9).

Posmatrano po okruzima, uočavaju se velike razlike, tako da je obezbeđenost lekarskim kadrom u Pirotskom (1178 stanovnika po lekaru) i Zaječarskom okrugu (1183), dvostruko veća nego u Podunavskom okrugu, gde jedan lekar pruža zdravstvenu zaštitu za 2494 odrasla stanovnika (Tabela 1). Lošija obezbeđenost od propisane prisutna je u čak 13 okruga. Uočava se da u Vojvodini svi okruzi, izuzev Srednjebanatskog, imaju lošiju obezbeđenost od propisane.

$\mathrm{Na} 100.000$ odraslih stanovnika Srbije zdravstvenu zaštitu je obezbeđivalo 64 izabranih lekara u službi za zdravstvenu zaštitu odraslih.
Stanovnici Srbije ostvarili su 27.746.116 poseta kod izabranih lekara u ovoj službi, od kojih 317.809 sistematskih i 64.029 kontrolnih pregleda, odnosno 7663 posete po lekaru (36,5 poseta dnevno po lekaru), što je za $4 \%$ više od propisane opterećenosti (7350 poseta godišnje po lekaru ili 35 dnevno). Najmanja prosečna opterećenost lekara po danu je u Zaječarskom (27 poseta dnevno), Beogradskom (28) i Braničevskom okrugu (31), a najveća u Podunavskom (čak skoro 58 poseta dnevno) i Sremskom okrugu (54). Iako 12 okruga ima povoljniju obezbeđenost od propisane, samo u 8 okruga je opterećenost lekara ista ili manja od propisane. Obezbeđenost lekarskim kadrom (1 lekar na 1600 stanovnika) koja je bolja od propisane je u Zlatiborskom, Jablaničkom, Pomoravskom, Srednjebanatskom i Mačvanskom okrugu, ali je opterećenost lekara veća od propisanih mera izvršenja, dok je suprotna situacija u Braničevskom okrugu. U ostalim okruzima opterećenost lekara je veća od propisane ukoliko je obezbeđenost lošija od propisane, i obrnuto.

Treba istaći da su izabrani lekari u službi za zdravstvenu zaštitu odraslih (ako je tako organizovana zdravstvena zaštita), u svim zdravstvenim ustanovama tokom 2017. godine, obavili i 251.607 kućnih poseta, što povećava njihovu opterećenost (tabela 1). 
Tabela 1. Broj lekara i poseta, obezbeđenost i opterećenost izabranih lekara u službi za zdravstvenu zaštitu odraslih u Srbiji u 2017. godini

Table 1. Number of physicians and visits, supply and workload of primary physicians in Adult Health Service in Serbia, 2017

\begin{tabular}{|c|c|c|c|c|c|c|c|}
\hline Region/Region & $\begin{array}{c}\text { Broj } \\
\text { lekara/ } \\
\text { Number } \\
\text { of } \\
\text { physicians }\end{array}$ & $\begin{array}{c}\text { Broj } \\
\text { poseta/ } \\
\text { Number of } \\
\text { visits }\end{array}$ & $\begin{array}{c}\text { Broj } \\
\text { poseta po } \\
\text { lekaru } \\
\text { godišnje/ } \\
\text { Number } \\
\text { of visits } \\
\text { per a } \\
\text { physician } \\
\text { vearly }\end{array}$ & $\begin{array}{c}\text { Broj } \\
\text { poseta po } \\
\text { lekaru u } \\
\text { toku } \\
\text { dana/ } \\
\text { Number of } \\
\text { visits per a } \\
\text { physician } \\
\text { daily } \\
\end{array}$ & $\begin{array}{c}\text { Broj } \\
\text { stanovnika } \\
20+ \\
\text { godina/ } \\
\text { Number of } \\
\text { people 20 } \\
\text { years and } \\
\text { older }\end{array}$ & $\begin{array}{c}\text { Broj } \\
\text { stanovnika } \\
\text { po lekaru/ } \\
\text { Number of } \\
\text { people per a } \\
\text { physician }\end{array}$ & $\begin{array}{c}\text { Broj } \\
\text { kućnih } \\
\text { poseta/ } \\
\text { Number } \\
\text { of home } \\
\text { visits }\end{array}$ \\
\hline R. Srbija & 3621 & 27.746 .116 & 7.663 & 36,5 & 5.661 .507 & 1.564 & 251.607 \\
\hline Beogradski & 1020 & 6.041 .981 & 5923 & 28,2 & 1.360 .875 & 1334 & 60.748 \\
\hline Mačvanski & 145 & 1.075 .787 & 7419 & 35,3 & 228.103 & 1573 & 14.056 \\
\hline Kolubarski & 97 & 643.084 & 6630 & 31,6 & 135.438 & 1396 & 15.629 \\
\hline Podunavski & 61 & 739.794 & 12.128 & 57,8 & 152.151 & 2494 & 3633 \\
\hline Braničevski & 78 & 514.255 & 6593 & 31,4 & 139.144 & 1784 & 2464 \\
\hline Šumadijski & 164 & 1.185 .969 & 7231 & 34,5 & 231.617 & 1412 & 19.349 \\
\hline Pomoravski & 104 & 768.717 & 7391 & 35,2 & 165.306 & 1589 & 16.388 \\
\hline Borski & 68 & 499.807 & 7350 & 35,0 & 95.071 & 1398 & 8268 \\
\hline Zaječarski & 78 & 453.850 & 5818 & 27,7 & 92.241 & 1183 & 7428 \\
\hline Zlatiborski & 150 & 1.343 .097 & 8954 & 42,6 & 218.800 & 1458 & 6028 \\
\hline Moravički & 89 & 780.791 & 8773 & 41,8 & 164.705 & 1851 & 268 \\
\hline Raški & 134 & 1.156 .922 & 8634 & 41,1 & 230.281 & 1719 & 566 \\
\hline Rasinski & 109 & 1.095 .600 & 10.051 & 47,9 & 185.627 & 1703 & 1790 \\
\hline Nišavski & 169 & 1.509 .795 & 8934 & 42,5 & 297.574 & 1761 & 3162 \\
\hline Toplički & 50 & 356.056 & 7121 & 33,9 & 68.592 & 1372 & 1657 \\
\hline Pirotski & 61 & 438.454 & 7188 & 34,2 & 71.847 & 1178 & 1152 \\
\hline Jablanički & 131 & 1.043 .779 & 7968 & 37,9 & 163.798 & 1250 & 14.668 \\
\hline Pčinjski & 83 & 656.399 & 7908 & 37,7 & 152.889 & 1842 & 586 \\
\hline Severnobački & 79 & 786.096 & 9950 & 47,4 & 145.928 & 1847 & 5431 \\
\hline Srednjebanatski & 105 & 829.578 & 7900 & 37,6 & 143.468 & 1366 & 6324 \\
\hline Severnobanatski & 60 & 560.336 & 9339 & 44,5 & 112.553 & 1876 & 3798 \\
\hline Južnobanatski & 129 & 1.100 .423 & 8530 & 40,6 & 226.407 & 1755 & 25.559 \\
\hline Zapadnobački & 85 & 750.264 & 8826 & 42,0 & 143.939 & 1693 & 9416 \\
\hline Južnobački & 251 & 2.033 .314 & 8101 & 38,6 & 491.427 & 1958 & 12.675 \\
\hline Sremski & 121 & 1.381 .968 & 11.421 & 54,4 & 243.726 & 2014 & 10.564 \\
\hline
\end{tabular}

Napomena: u zatamnjenim poljima su okruzi koji imaju nepovoljnu obezbeđenost i opterećenost u odnosu na zakonski propisanu.

\section{Služba za zdravstvenu zaštitu male i predškolske dece}

U službi za zdravstvenu zaštitu male i predškolske dece u 2017. godini na primarnom nivou u Srbiji, 623 izabrana lekara (604 specijalista pedijatrije i 19 lekara opšte medicine) su pružala zdravstvenu zaštitu za 458.199 dece uzrasta 0-6 godina. To znači, da je u proseku svaki lekar obezbeđivao zdravstvenu zaštitu za 735 dece. Obezbeđenost lekarskim kadrom u ovoj službi na nivou Srbije bila je znatno bolja (za 13,5\%) od one koju je propisalo Ministarstvo zdravlja (850 dece po lekaru specijalisti pedijatrije) (9).

I u ovoj službi postoje velike regionalne razlike: obezbeđenost lekarskim kadrom u Pirotskom (496 dece po lekaru) i Kolubarskom okrugu (526), dvostruko je veća nego u Severnobačkom okrugu (1015). Lošija obezbeđenost od propisane prisutna je u 7 okruga (Beogradski okrug i svi okruzi u Vojvodini, sem Severnobanatskog).

$\mathrm{Na} 100.000$ dece uzrasta 0-6 godina u Srbiji, zdravstvenu zaštitu je obezbeđivalo 
136 izabranih lekara u službi za zdravstvenu zaštitu male i predškolske dece. Mala i predškolska deca su ostvarila 4.008.446 poseta izabranim lekarima u ovoj službi (od kojih 452.421 sistematski i 131.180 kontrolni pregled), odnosno 6.434 posete po lekaru (30,6 poseta dnevno po lekaru), što je za $2 \%$ više od propisane opterećenosti (6300 poseta godišnje po lekaru ili 30 poseta dnevno po lekaru).

Najmanja prosečna opterećenost izabranog lekara (broj poseta dnevno po lekaru) je u Kolubarskom okrugu $(20,0)$ i Srednjebanatskom okrugu $(21,5)$, a najveća u Topličkom $(39,0)$, Jablaničkom i Sremskom okrugu (preko 36). Prosečna opterećenost lekara veća od propisane, je u 10 okruga. U Moravičkom, Nišavskom, Jablaničkom, Šumadijskom i Topličkom okrugu, obezbeđenost lekarskim kadromje bolja od propisane, alije opterećenost lekara veća od propisanih mera izvršenja, dok je situacija suprotna u Severnobačkom i Srednjebanatskom okrugu. U ostalim okruzima opterećenost izabranih lekara je veća od propisane ukoliko je obezbeđenost lošija od propisane, $\mathrm{i}$ obrnuto.

Broj kućnih poseta koje su obavili lekari iz službi za zdravstvenu zaštitu male i predškolske dece je samo 933 u 2017. godini u celoj Srbiji (Tabela 2).

Tabela 2. Broj lekara i poseta, obezbeđenost i opterećenost izabranih lekara u službi za zdravstvenu zaštitu dece (0-6g.) u Srbiji u 2017. godini

Table 2. Number of doctors and visits, supply and workload of primary physicians in the Child Health Service (0-6g) in Serbia, 2017

\begin{tabular}{|c|c|c|c|c|c|c|}
\hline Region/Region & $\begin{array}{c}\text { Broj } \\
\text { lekara/ } \\
\text { Number } \\
\text { of } \\
\text { physicians }\end{array}$ & $\begin{array}{c}\text { Broj } \\
\text { poseta/ } \\
\text { Number of } \\
\text { visits }\end{array}$ & $\begin{array}{c}\text { Broj } \\
\text { poseta po } \\
\text { lekaru } \\
\text { godišnje/ } \\
\text { Number of } \\
\text { visits per a } \\
\text { physician } \\
\text { yearly }\end{array}$ & \begin{tabular}{|c|} 
Broj \\
poseta po \\
lekaru u \\
toku \\
dana/ \\
Number of \\
visits per a \\
physician \\
daily \\
\end{tabular} & $\begin{array}{c}\text { Broj dece } \\
0-6 \text { godina/ } \\
\text { Number of } \\
\text { children 0-6 } \\
\text { years old }\end{array}$ & $\begin{array}{c}\text { Broj } \\
\text { dece po } \\
\text { lekaru/ } \\
\text { Number of } \\
\text { children } \\
\text { per a } \\
\text { physician }\end{array}$ \\
\hline R. Srbija & 623 & 4.008 .446 & 6.434 & 30,6 & 458.199 & 735 \\
\hline Beogradski & 142 & 1.052 .975 & 7415 & 35,3 & 124.467 & 876 \\
\hline Mačvanski & 33 & 172.170 & 5218 & 24,8 & 17.520 & 531 \\
\hline Kolubarski & 18 & 75.628 & 4202 & 20,0 & 9464 & 526 \\
\hline Podunavski & 20 & 99.693 & 4984 & 23,8 & 11.315 & 566 \\
\hline Braničevski & 15 & 84.274 & 5619 & 26,8 & 9152 & 611 \\
\hline Šumadijski & 28 & 183.078 & 6538 & 31,2 & 17.802 & 636 \\
\hline Pomoravski & 20 & 116.524 & 5826 & 27,7 & 11.490 & 574 \\
\hline Borski & 9 & 48.377 & 5376 & 25,6 & 6121 & 681 \\
\hline Zaječarski & 8 & 46.263 & 5783 & 27,5 & 5434 & 679 \\
\hline Zlatiborski & 29 & 144.240 & 4974 & 23,7 & 16.481 & 568 \\
\hline Moravički & 21 & 137.992 & 6571 & 31,3 & 12.166 & 580 \\
\hline Raški & 29 & 168.124 & 5797 & 27,6 & 24.120 & 832 \\
\hline Rasinski & 20 & 121.369 & 6068 & 28,9 & 12.542 & 627 \\
\hline Nišavski & 32 & 230.569 & 7205 & 34,3 & 22.275 & 696 \\
\hline Toplički & 8 & 65.619 & 8202 & 39,0 & 5186 & 648 \\
\hline Pirotski & 9 & 56.190 & 6244 & 29,8 & 4461 & 496 \\
\hline Jablanički & 18 & 136.894 & 7606 & 36,2 & 12.019 & 668 \\
\hline Pčinjski & 25 & 135.776 & 5431 & 25,9 & 13.415 & 536 \\
\hline Severnobački & 11 & 59.022 & 5366 & 25,6 & 11.157 & 1015 \\
\hline Srednjebanatski & 12 & 54.187 & 4516 & 21,5 & 11.055 & 921 \\
\hline Severnobanatski & 12 & 67.599 & 5633 & 26,8 & 8111 & 676 \\
\hline Južnobanatski & 20 & 142.870 & 7143 & 34,0 & 17.874 & 894 \\
\hline Zapadnobački & 11 & 78.060 & 7097 & 33,8 & 9814 & 893 \\
\hline Južnobački & 50 & 354.322 & 7086 & 33,7 & 45.515 & 910 \\
\hline Sremski & 23 & 176.631 & 7680 & 36,6 & 19.243 & 837 \\
\hline
\end{tabular}

Napomena: u zatamnjenim poljima su okruzi koji imaju nepovoljnu obezbeđenost i opterećenost u odnosu na propisanu. 


\section{Služba za zdravstvenu zaštitu školske dece}

U službi za zdravstvenu zaštitu školske dece u 2017. godini u zdravstvenim ustanovama primarne zaštite u Srbiji, 553 izabrana lekara (427 specijalista i 126 lekara opšte medicine) su pružala zdravstvenu zaštitu za 901.152 dece uzrasta 7-19 godina. To znači, da je u proseku svaki lekar obezbeđivao zdravstvenu zaštitu za 1630 školske dece. Obezbeđenost lekarskim kadrom u ovoj službi u 2017. na nivou Srbije bila je za $9 \%$ lošija od one koju je propisalo Ministarstvo zdravlja (1500 školske dece po lekaru) (9).

Regionalne razlike u ovoj službi su najizraženije. Obezbeđenost lekarskim kadrom u Borskom (801 školsko dete po lekaru) i Pirotskom okrugu (965), je tri puta veća, nego u Mačvanskom (2670) i Srednjebanatskom okrugu (2532). Lošija obezbeđenost od propisane prisutna je u čak 17 okruga (Tabela 3 ). Uočava se da u Vojvodini svi okruzi, izuzev Sremskog, imaju lošiju obezbeđenost lekarima od propisane.

Tabela 3. Broj lekara i poseta, obezbeđenost i opterećenost izabranih lekara u službi za zdravstvenu zaštitu školske dece u 2017. godini u Srbiji

Table 3. Number of physicians and visits, supply and workload of primary physicians at the School Children Health Service in Serbia, 2017

\begin{tabular}{|c|c|c|c|c|c|c|}
\hline Region/Region & $\begin{array}{c}\text { Broj } \\
\text { lekara/ } \\
\text { Number } \\
\text { of } \\
\text { physicians }\end{array}$ & $\begin{array}{c}\text { Broj } \\
\text { poseta/ } \\
\begin{array}{c}\text { Number of } \\
\text { visits }\end{array}\end{array}$ & $\begin{array}{c}\text { Broj } \\
\text { poseta po } \\
\text { lekaru } \\
\text { godišnje/ } \\
\text { Number } \\
\text { of visits } \\
\text { per a } \\
\text { physician } \\
\text { vearly }\end{array}$ & $\begin{array}{c}\text { Broj } \\
\text { poseta po } \\
\text { lekaru u } \\
\text { toku } \\
\text { dana/ } \\
\text { Number of } \\
\text { visits per a } \\
\text { chosen } \\
\text { physician } \\
\text { daily }\end{array}$ & $\begin{array}{l}\text { Broj dece } \\
7-19 \\
\text { godina/ } \\
\text { Number of } \\
\text { children } \\
7-19 \text { vears } \\
\text { old }\end{array}$ & $\begin{array}{c}\text { Broj } \\
\text { dece po } \\
\text { lekaru/ } \\
\text { Number } \\
\text { of } \\
\text { children } \\
\text { per a } \\
\text { physician }\end{array}$ \\
\hline R. Srbija & 553 & 3.486 .222 & 6.304 & 30,0 & 901.152 & 1.630 \\
\hline Beogradski & 120 & 808.088 & 6.734 & 32,1 & 201.790 & 1682 \\
\hline Mačvanski & 14 & 133.488 & 9.535 & 45,4 & 37.384 & 2670 \\
\hline Kolubarski & 9 & 70.933 & 7.881 & 37,5 & 20.371 & 2264 \\
\hline Podunavski & 17 & 91.659 & 5.392 & 25,7 & 25.625 & 1507 \\
\hline Braničevski & 18 & 89.739 & 4.986 & 23,7 & 21.911 & 1218 \\
\hline Šumadijski & 23 & 181.857 & 7.907 & 37,6 & 35.538 & 1545 \\
\hline Pomoravski & 19 & 133.349 & 7.018 & 33,4 & 25.229 & 1328 \\
\hline Borski & 17 & 62.098 & 3.653 & 17,4 & 13.624 & 801 \\
\hline Zaječarski & 8 & 46.456 & 5.807 & 27,6 & 11.959 & 1495 \\
\hline Zlatiborski & 22 & 127.677 & 5.804 & 27,6 & 35.799 & 1628 \\
\hline Moravički & 16 & 90.325 & 5.645 & 26,9 & 25.155 & 1572 \\
\hline Raški & 26 & 138.997 & 5.346 & 25,5 & 51.553 & 1983 \\
\hline Rasinski & 19 & 122.037 & 6.423 & 30,6 & 28.639 & 1507 \\
\hline $\mathrm{Nišavski}$ & 28 & 162.890 & 5.818 & 27,7 & 44.308 & 1582 \\
\hline Toplički & 10 & 59.945 & 5.995 & 28,5 & 11.509 & 1151 \\
\hline Pirotski & 10 & 53.252 & 5.325 & 25,3 & 9.656 & 965 \\
\hline Jablanički & 18 & 122.426 & 6.801 & 32,4 & 27.437 & 1525 \\
\hline Pčinjski & 22 & 121.832 & 5.538 & 26,4 & 32.367 & 1472 \\
\hline Severnobački & 12 & 77.984 & 6.499 & 30,9 & 23.264 & 1939 \\
\hline Srednjebanatski & 9 & 64.790 & 7.199 & 34,3 & 22.785 & 2532 \\
\hline Severnobanatski & 9 & 58.333 & 6.481 & 30,9 & 17.707 & 1968 \\
\hline Južnobanatski & 22 & 160.145 & 7.279 & 34,7 & 36.922 & 1679 \\
\hline Zapadnobačlki & 11 & 77.141 & 7.013 & 33,4 & 21.594 & 1964 \\
\hline Južnobački & 46 & 292.628 & 6.361 & 30,3 & 81.007 & 1761 \\
\hline Sremski & 28 & 138.153 & 4.934 & 23,5 & 38.019 & 1358 \\
\hline
\end{tabular}

Napomena: u zatamnjenim poljima su okruzi koji imaju nepovoljnu obezbeđenost i na propisanu.

opterećenost u odnosu 
$\mathrm{Na} 100.000$ dece uzrasta 7-19 godina $u$ Srbiji, zdravstvenu zaštitu je obezbeđivao 61 izabrani lekar u službi za zdravstvenu zaštitu školske dece.

Školska deca su ostvarila 3.486.222 posete izabranim lekarima u ovoj službi u 2017. godini na nivou Srbije (uključujući i 312.330 sistematskih pregleda), odnosno 6.304 posete po lekaru (30 poseta dnevno po lekaru), što je na nivou propisane opterećenosti $(6300$ poseta godišnje po lekaru ili 30 poseta dnevno). Najmanja prosečna dnevna opterećenost posetama izabranog lekara je u Borskom $(17,4)$ i Sremskom okrugu $(23,5)$, a najveća u Mačvanskom $(45,4)$, a zatim u Sumadijskom i Kolubarskom okrugu (skoro 38). Iako 17 okruga ima lošiju obezbeđenost od propisane, u 12 okruga je opterećenost lekara veća od propisane, a u Podunavskom, Zlatiborskom, Moravičkom, Raškom i Nišavskom okrugu je opterećenost manja od propisane. Jedino je u Pomoravskom okrugu opterećenost veća, a obezbeđenost lekarima povoljnija od propisane, dok je u ostalim okruzima povoljna obezbeđenost praćena manjim opterećenjem lekara od propisanih mera izvršenja.

Broj kućnih poseta koje su obavili lekari u službama za zdravstvenu zaštitu školske dece je samo 328 u 2017. godini u celoj Srbiji.

\section{Služba za zdravstvenu zaštitu žena}

U službi za zdravstvenu zaštitu žena u 2017. godini u domovima zdravlja i zavodima na primarnom nivou u Srbiji, 464 izabranih lekara specijalista ginekologije su pružala zdravstvenu zaštitu za 3.111.802 žene starosti 15 i više godina. $U$ proseku, svaki lekar obezbeđivao je zdravstvenu zaštitu za 6.706 žena. Obezbeđenost lekarskim kadrom u ovoj službi na nivou Srbije, bila je za 3\% lošija od one koju je propisalo Ministarstvo zdravlja
(6500 žena preko 15 godina po lekaru) (9).

I u ovoj službi su izražene regionalne razlike. Obezbeđenost lekarskim kadrom u Pirotskom (4157 žena po lekaru) i Pčinjskom okrugu (4875), je dvostruko veća u odnosu na Sumadijski (12.609) i Severnobački okrug (10.126). Lošija obezbeđenost od propisane prisutna je u 13 okruga, među kojima su svi okruzi u Vojvodini, sem Sremskog (Tabela 4).

$\mathrm{Na} 100.000$ žena starih 15 i više godina u Srbiji, zdravstvenu zaštitu je obezbeđivalo 15 izabranih ginekologa u službi za zdravstvenu zaštitu žena.

U službi za zdravstvenu zaštitu žena u 2017. godini je registrovano 1.752 .145 poseta izabranim ginekolozima u ordinaciji (od kojih je 389.425 sistematskih pregleda), 645.871 prvih poseta savetovalištu za trudnice i 150.552 posete savetovalištu za planiranje porodice. Ukupno je obavljeno 2.548 .568 poseta kod izabranih ginekologa, odnosno 5.493 posete godišnje po lekaru (26,2 posete dnevno po lekaru), što je za $11,5 \%$ manje od propisane opterećenosti (6300 poseta godišnje po lekaru ili 30 poseta dnevno). Najmanja prosečna dnevna opterećenost lekara je u Mačvanskom $(11,0)$, Pirotskom $(15,1)$, Braničevskom $(16,3)$ i Podunavskom $(17,0)$, a najveća u Sumadijskom $(43,1)$ i Rasinskom okrugu $(39,5)$. Pored Šumadijskog i Rasinskog, u još četiri okruga je prosečna dnevna opterećenost lekara veća od propisanih mera izvršenja (Zapadnobački, Južnobanatski, Nišavski i Jablanički). U Nišavskom i Jablaničkom okrugu obezbeđenost izabranim ginekolozima je povoljnija od propisane, a u preostala 4 okruga je nepovoljnija. Iako je u još 9 okruga obezbeđenost lekarskim kadrom lošije od propisane, opterećenost lekara je manja od propisanih mera izvršenja.

Lekari specijalisti ginekologije i akušerstva su obavili 179 kućnih poseta u 2017. godini, i to 177 u Nišavskom i 2 kućne 
Tabela 4. Broj lekara i poseta, obezbeđenost i opterećenost izabranih lekara u službi za zdravstvenu zaštitu žena u 2017. godini u Srbiji

Table 4. Number of doctors and visits, supply and workload of primary doctors at the Women's Health Service in Serbia, 2017

\begin{tabular}{|c|c|c|c|c|c|c|}
\hline Region/Region & $\begin{array}{c}\text { Broj } \\
\text { lekara/ } \\
\text { Number } \\
\text { of } \\
\text { physicians }\end{array}$ & $\begin{array}{c}\text { Broj } \\
\text { poseta/ } \\
\text { Number } \\
\text { of visits }\end{array}$ & $\begin{array}{c}\text { Broj } \\
\text { poseta po } \\
\text { lekaru } \\
\text { godišnje/ } \\
\text { Number } \\
\text { of visits } \\
\text { per a } \\
\text { physician } \\
\text { vearly }\end{array}$ & $\begin{array}{c}\text { Broj } \\
\text { poseta po } \\
\text { lekaru u } \\
\text { toku } \\
\text { dana/ } \\
\text { Number } \\
\text { of visits } \\
\text { per a } \\
\text { physician } \\
\text { daily } \\
\end{array}$ & $\begin{array}{c}\text { Broj žena } \\
\text { (15 i više } \\
\text { godina)/ } \\
\text { Number of } \\
\text { women (15 } \\
\text { vears of } \\
\text { age and } \\
\text { older) }\end{array}$ & $\begin{array}{c}\text { Broj } \\
\text { żena po } \\
\text { lekaru/ } \\
\text { Number of } \\
\text { women } \\
\text { per a } \\
\text { physician }\end{array}$ \\
\hline R. Srbija & 464 & 2.548 .568 & 5.493 & 26,2 & 3.111 .802 & 6.706 \\
\hline Beogradski & 119 & 717.580 & 6.030 & 28,7 & 768.211 & 6456 \\
\hline Mačvanski & 20 & 46.074 & 2.304 & 11,0 & 123.163 & 6158 \\
\hline Kolubarski & 9 & 46.672 & 5.186 & 24,7 & 72.617 & 8069 \\
\hline Podunavski & 13 & 46.320 & 3.563 & 17,0 & 82.675 & 6360 \\
\hline Braničevski & 13 & 44.605 & 3.431 & 16,3 & 76.560 & 5889 \\
\hline Šumadijski & 10 & 90.547 & 9.055 & 43,1 & 126.087 & 12.609 \\
\hline Pomoravski & 17 & 78.070 & 4.592 & 21,9 & 91.103 & 5359 \\
\hline Borski & 7 & 27.655 & 3.951 & 18,8 & 51.765 & 7395 \\
\hline Zaječarski & 5 & 23.729 & 4.746 & 22,6 & 49.911 & 9982 \\
\hline Zlatiborski & 18 & 105.367 & 5.854 & 27,9 & 118.222 & 6568 \\
\hline Moravički & 15 & 62.602 & 4.173 & 19,9 & 89.559 & 5970 \\
\hline Raški & 20 & 84.236 & 4.212 & 20,1 & 126.974 & 6349 \\
\hline Rasinski & 14 & 116.117 & 8.294 & 39,5 & 100.682 & 7191 \\
\hline Nišavski & 26 & 173.816 & 6.685 & 31,8 & 161.597 & 6215 \\
\hline Toplički & 7 & 30.139 & 4.306 & 20,5 & 36.461 & 5209 \\
\hline Pirotski & 9 & 28.536 & 3.171 & 15,1 & 37.408 & 4157 \\
\hline Jablanički & 14 & 88.580 & 6.327 & 30,1 & 87.955 & 6282 \\
\hline Pčinjski & 17 & 89.232 & 5.249 & 25,0 & 82.872 & 4875 \\
\hline Severnobački & 8 & 41.260 & 5.158 & 24,6 & 81.005 & 10.126 \\
\hline Srednjebanatski & 10 & 52.294 & 5.229 & 24,9 & 78.399 & 7840 \\
\hline Severnobanatski & 8 & 39.174 & 4.897 & 23,3 & 61.539 & 7692 \\
\hline Južnobanatski & 16 & 102.829 & 6.427 & 30,6 & 123.115 & 7695 \\
\hline Zapadnobački & 8 & 53.882 & 6.735 & 32,1 & 78.535 & 9817 \\
\hline Južnobački & 40 & 228.827 & 5.721 & 27,2 & 273.297 & 6832 \\
\hline Sremski & 21 & 130.425 & 6.211 & 29,6 & 132.090 & 6290 \\
\hline
\end{tabular}

Napomena: u zatamnjenim poljima su okruzi koji imaju nepovoljnu obezbeđenost i opterećenost u odnosu na propisanu. 
posete u Južnobanatskom okrugu.

\section{Diskusija}

U Srbiji u 2017. godini zdravstvenu zaštitu je obezbeđivalo 75 izabranih lekara na 100.000 stanovnika, od kojih 64 izabrana lekara u službi za zdravstvenu zaštitu odraslih. Podaci za Evropu pokazuju da je u proseku 68 lekara opšte prakse/porodičnih lekara na 100.000 stanovnika, sa velikim razlikama između država (od 47 u Holandiji do 115 u Belgiji) (10). Međutim, sistemi primarne zdravstvene zaštite se razlikuju kako po strukturnim elementima (regulativa, finansiranje, kadar), tako i po pristupačnosti, kontinuitetu zdravstvene zaštite i zdravstvenim uslugama koje pružaju (10). Pored porodičnog lekara, u mnogim državama su i različiti specijalisti deo sistema primarne zdravstvene zaštite (ginekolozi, pedijatri, internisti, oftalmolozi, neurolozi i dr.) (11).

Zbog navedenih razlika $u$ sistemima primarne zdravstvene zaštite, u ovom radu obezbeđenost izabranim lekarima nije upoređivana sa drugim državama, već samo sa vrednostima propisanim za R. Srbiju (9). U 2017. godini u Srbiji je obezbeđenost izabranim lekarima bila veća od propisane u službi za zdravstvenu zaštitu odraslih za $2 \%$, a u službi za zdravstvenu zaštitu male i predškolske dece za $13,5 \%$ (odnosno, za $8 \%$ kada ne bi računali lekare opšte medicine, koji nisu predviđeni regulativom u ovoj službi). Nedostatak lekara, odnosno obezbeđenost manja od propisane, prisutna je u službi za zdravstvenu zaštitu školske dece za $9 \%$ i za zdravstvenu zaštitu žena za 3\%. Prilikom izračunavanja nivoa obezbeđenosti nisu uzimani u obzir lekari na specijalizaciji, jer smo smatrali da su oni u procesu stručnog usavršavanja i da u nekim službama ne učestvuju u pružanju zdravstvene zaštite ili učestvuju samo jednim delom vremena, koje nije moguće proceniti zbog različitih praksi u zdravstvenim ustanovama. Takođe, ovi lekari su upućeni na specijalizaciju najčešće da bi se omogućila pravovremena zamena kadra, za koji se planira odlazak u penziju, ali tako da se posle njihovog završetka specijalizacije neće povećati broj izabranih lekara. Ni u propisima koji uređuju kadrovsku obezbeđenost, ne spominju se lekari na specijalizaciji.

Međutim, kada bi se uračunali i lekari na specijalizaciji, obezbeđenost izabranim lekarima bila bi značajno promenjena i čak veća od propisane i u službi za zdravstvenu zaštitu žena (sa 6706 smanjila bi se na 5849 žena starih 15 i više godina po lekaru) i u službi za zdravstvenu zaštitu školske dece (sa 1630 na 1412 školske dece po lekaru).

Iako dobijeni rezultati ukazuju da postoji višak lekara u službama za zdravstvenu zaštitu odraslih i zdravstvenu zaštitu male $i$ predškolske dece, kada se u analizu uključi i parametar opterećenost, uočava se da je u obe službe opterećenost izabranih lekara veća od propisanih mera izvršenja (9). U službi za zdravstvenu zaštitu odraslih u 2017. godini u Srbiji je ostvareno u proseku po 36,5 poseta po lekaru (za $4 \%$ više od propisanih 35 dnevno), a u službi za zdravstvenu zaštitu male i predškolske dece 30,6 poseta po lekaru (za 2\% više od propisanih 30 poseta dnevno). Prilikom analiziranja opterećenosti izabranih lekara nisu uzete u obzir kućne posete koje su obavili lekari, s obzirom da zahtevaju znatno više vremena od poseta u ordinaciji, što usložnjava izračunavanje opterećenosti. Sem toga, postoji i različita organizacija u domovima zdravlja za obavljanje kućnih poseta: od posebnih organizacionih jedinica, do toga da izabrani lekar koji radi u ordinaciji, odlazi u kućnu posetu. Kućne posete dodatno povećavaju opterećenost izabranih lekara, posebno u službama za zdravstvenu zaštitu odraslih, gde je u 2017. godini obavljeno preko 250.000 kućnih poseta.

Imajući u vidu starenje stanovnika Srbije i povećanje broja novoobolelih (incidencije, sledstveno tome i prevalencije) od hroničnih nezaraznih bolesti, može se očekivati dalje povećanje opterećenosti izabranih lekara u službi za zdravstvenu zaštitu odraslih.

Treba naglasiti da je u Srbiji u 2017. godini radilo još 263 lekara u službi medicine rada (83 lekara opšte medicine, 11 na specijalizaciji i 169 specijalista), kod kojih je ostvareno 1.554 .016 poseta odraslih stanovnika. Iz rutinskih statističkih podataka nije moguće sagledati u kom obimu su lekari ove službe bili angažovani kao izabrani lekari. Međutim, kada bi se oni svi uračunali u izabrane lekare u službi za zdravstvenu zaštitu odraslih, opet bi prosečna opterećenost bila veća od propisane.

U službi za zdravstvenu zaštitu školske dece opterećenost izabranih lekara je u skladu sa propisanim merama izvršenja, iako je obezbeđenost manja od propisane. U službi za zdravstvenu zaštitu žena, prosečna opterećenost lekara specijalista ginekologije (26,2 poseta dnevno) je za 3.8\% manja od propisanih mera izvršenja (30 poseta dnevno), a i obezbeđenost ginekolozima je manja od propisane. Treba naglasiti da, prilikom izračunavanja opterećenosti izabranih 
ginekologa nisu uračunati kontrolni pregledi u savetovalištu za trudnice, s obzirom da ih nije bilo moguće dobiti od Instituta za javno zdravlje Srbije.

Ukoliko se obezbeđenost i opterećenost izabranih lekara posmatraju po okruzima, uočavaju se izrazite regionalne razlike u svim službama. Tako je u službi za zdravstvenu zaštitu odraslih obezbeđenost nepovoljnija od propisane u 13 okruga, a opterećenost u čak 17 okruga. Obezbeđenost lekarskim kadrom u Pirotskom (1178 stanovnika po lekaru) i Zaječarskom okrugu (1183), dvostruko je veća nego u Podunavskom okrugu (2494). Najmanja prosečna dnevna opterećenost izabranog lekara je u Zaječarskom okrugu (27,7 poseta dnevno) i Beogradskom okrugu $(28,2)$, a najveća u Podunavskom (čak 57,8) i Sremskom okrugu $(54,4)$. Zbog ovako visoke opterećenosti u ova dva okruga potrebno je dodatno istraživanje da se ustanovi da li je uzrok nedostatak lekara ili postoji i drugi pridruženi faktori, kao što je način evidentiranja i izveštavanja broja poseta $\mathrm{i}$ dr.

U službi za zdravstvenu zaštitu male i predškolske dece obezbeđenost je manja od propisane u 7 , a opterećenost je veća u 10 okruga. Obezbeđenost lekarskim kadrom u Pirotskom (496 dece po lekaru) i Kolubarskom okrugu (526), je dvostruko veća nego u Severnobačkom okrugu (1014). Najmanja prosečna opterećenost izabranog lekara je u Kolubarskom okrugu (20,0 poseta dnevno) i Srednjebanatskom okrugu $(21,5)$, a najveća u Topličkom (39,0 poseta dnevno), Jablaničkom i Sremskom okrugu (preko 36 poseta).

U službi za zdravstvenu zaštitu školske dece obezbeđenost je nepovoljna u čak 17, a opterećenost veća od propisane u 13 okruga. Obezbeđenost lekarskim kadrom u Borskom (801 dete po lekaru) i Pirotskom (965), je tri puta veća nego u Mačvanskom (2670) i Srednjebanatskom okrugu (2532). Najmanja prosečna opterećenost izabranog lekara je u Borskom (17,4 poseta dnevno) i Sremskom okrugu $(23,5)$, a najveća u Mačvanskom $(45,4$ posete dnevno), a zatim u Šmadijskom i Kolubarskom okrugu (oko 38 poseta dnevno).

U službi za zdravstvenu zaštitu žena obezbeđenost je nepovoljna u 11, a opterećenost veća od propisane u 6 okruga. Obezbeđenost lekarskim kadrom u Pirotskom (4157 žena po lekaru) i Pčinjskom okrugu (4875), je više nego dvostruko je veća u odnosu na Sumadijski (12.609) i Severnobački okrug (10.126). Najmanja prosečna opterećenost izabranog ginekologa je u Mačvanskom (11,0 poseta dnevno), a najveća u Šumadijskom
$(43,1)$ i Rasinskom okrugu $(39,5$ poseta dnevno).

Dobijeni rezultati pokazuju da se Pirotski okrug izdvaja po dobroj obezbeđenosti izabranim lekarima, koja je znatno povoljnija od propisane u svim službama, dok okruzi u Vojvodini imaju manju obezbeđenost od propisane.

Neravnomernost $\mathrm{u}$ stepenu ekonomske razvijenosti regiona u Republici Srbiji predstavlja jedno od najkompleksnijih razvojnih problema države utičući i na različit demografski razvoj regiona u Srbiji (12). Različita privredna razvijenost regiona povlači za sobom i neravnomernu raspodelu zdravstvenog osoblja između i unutar zemalja, što je dugotrajan i ozbiljan problem, prisutan kako u bogatim, tako i u siromašnim zemljama. Prema podacima OECD iz 2012. godine, od ukupno 34 zemlje, samo Holandija nije smatrala da je regionalna raspodela lekara problem (13).

Posebno treba istaći da, korišćenje rutinskih statističkih podataka za izračunavanje opterećenosti izabranih lekara zahteva oprez i dobro poznavanje sistema izveštavanja, s obzirom da publikovani podaci u zdravstvenostatističkom godišnjaku Instituta za javno zdravlje Srbije „Dr Milan Jovanović-Batut“ ne sadrže sistematske i kontrolne preglede školske dece, kao ni posete savetovalištu za trudnice i savetovalištu za planiranje porodice, zbog čega se dobija lažna slika opterećenosti izabranih lekara. Za potrebe ovog rada navedeni podaci su dobijeni od Instituta za javno zdravlje Srbije na zahtev autora.

\section{Zaključak}

Obezbeđenost izabranim lekarima u Srbiji u službama za zdravstvenu zaštitu odraslih i zdravstvenu zaštitu male i predškolske dece je manja od propisane, dok je u službama za zdravstvenu zaštitu školske dece i zdravstvenu zaštitu žena, veća od propisane. Međutim, opterećenost izabranih lekara je veća od propisanih mera izvršenja u službi za zdravstvenu zaštitu odraslih, dok je u službama za zdravstvenu zaštitu male i predškolske dece i zdravstvenu zaštitu školske dece, na nivou propisanih mera izvršenja. Opterećenost ginekologa je ispod propisanih mera izvršenja.

Postoje velike razlike po okruzima i u obezbeđenosti i u opterećenosti izabranih lekara. Pirotski okrug se izdvaja po dobroj obezbeđenosti izabranim lekarima, koja je znatno povoljnija od propisane u svim službama, dok okruzi u Vojvodini imaju manju obezbeđenost od propisane. 
Prilikom planiranja humanih resursa, potrebno je uključiti oba parametra, i obezbeđenost i opterećenost, a mere kadrovske politike treba da omoguće smanjenje razlika između okruga.

Iako izračunavanje obezbeđenosti, kao i opterećenosti lekarskog kadra deluje jednostavno, postoje brojna ograničenja i poteškoće prilikom korišćenja rutinskih statističkih podataka za izračunavanje ovih parametara, a različiti pristupi, poput uključivanja ili isključivanja lekara na specijalizaciji, ili sistematskih i kontrolnih pregleda i poseta u savetovalištima, mogu uticati na dobijanje potpuno različitih i suprotnih rezultata. Potrebno je definisati jasna pravila i smernice na nacionalnom nivou kako bi se omogućilo dobijanje realne slike i preduzele mere za smanjenje razlika $\mathrm{u}$ obezbeđenosti izabranim lekarima i u njihovoj opterećenosti po okruzima.

Propisane mere izvršenja za izabrane lekare treba preispitati u kontekstu promena nastalih u sistemu primarne zdravstvene zaštite (uvođenje integrisanog zdravstvenog informacionog sistema, elektronskog kartona, elektronskog recepta i sl.), kao i većih očekivanja u segmentu preventivne zaštite i promocije zdravlja.

\section{Literatura}

1. Kringos DS, Boerma W, Van der Zww J, Groenewegwn P. Europe's strong primary care systems are linked to better population health but also to higher health spending. Health Affairs 2013; 32(4):686-94.

2. Macinko J, Starfield B, Shi L. The contribution of primary care systems to health outcomes within Organisation for Economic Co-operation and Development (OECD), 1970-1998. Health Serv Res 2003; 38, (3):831-65.

3. Zakon o zdravstvenoj zaštiti. ,Službeni glasnik RS“ br. 107/05.

4. Costa de MP, Giurgiuca A, Holmes K, Biskup E, Mogren T, Tomori S, et el. To which countries do European psychiatric trainees want to move to and why? Eur Psychiatry 2017; 45:174-81.

5. Roberfroid D, Stordeur S, Camberlin C, Voorde
Van de C, Vrijens F, Leonard C. Physician workforce supply in Belgium: current situation and challenges. Brussels: Belgian Health Care Knowledge Centre, 2008.

6. Santric-Milicevic M, Vasic V, Terzic-Supic Z. Do health care workforce, population, and service provision significantly contribute to the total health expenditure? An econometric analysis of Serbia. Human Resources for Health 2016; 14:50.

7. WHO. Global Health Workforce Alliance: Annual Report, 2014. Available at: http:/www.who.int/ workforcealliance/media/news/2014/jc begins/en/

8. Institut za javno zdravlje Srbije „Dr Milan Jovanović-Batut". Zdravstveno-statistički "godišnjak. Beograd: Institut za javno zdravlje Srbije „Dr Milan Jovanović-Batut", 2017.

9. Pravilnik o bližim uslovima za obavljanje zdravstvene delatnosti u zdravstvenim ustanovama i drugim oblicima obavljanja zdravstvene delatnosti. „Službeni glasnik RS“ br. 42/06, 112/09, 50/10, 79/11, 10/12 - dr. pravilnik, 119/12 - dr. pravilnik, 22/13, 16/18.

10. Boerma W, Bourgueil Y, Cartier T, Hasvold T, Hutchinson A, Kringos D, Kroneman M. Overview and future challenges for primary care. In: Kringos DS, Boerma WGW, Hutchinson A, et al., editors. Building primary care in a changing Europe [Internet]. Copenhagen (Denmark): European Observatory on Health Systems and Policies, 2015. Available at: https://www.ncbi. nlm.nih.gov/books/NBK458729/

11. Lember M, Cartier T, Bourgueil Y, Dedeu T, Hutchinson A, Kringos D. Structure and organization of primary care. In: Kringos DS, Boerma WGW, Hutchinson A, et al., editors. Building primary care in a changing Europe: Case studies [Internet]. Copenhagen (Denmark): European Observatory on Health Systems and Policies, 2015. Available at: https://www.ncbi.nlm. nih.gov/books/NBK459003/

12. Petrović J, Raduković S, Radović M. Višekriterijumska analiza nivoa demografskog razvoja regiona u Srbiji. Poslovna ekonomija 2017; 2:102-13.

13. Ono T, Schoenstein M, Buchan J. Geographic imbalances in doctor supply and policy responses. OECD Health Working Papers, No. 69. Paris: OECD Publishing, 2014. Available at: http://dx.doi. org/10.1787/5jz5sq5ls1wl-en

Conflict of interest: None declared.

Received (primljen): 06/20/2019

Revised (revizija): 09/25/2019

Accepted (prihvaćen): 09/26/2019

Online first: 09/30/2019

Kontakt: prim. dr sci. med. Zdenka Janković, Narodnih heroja 41-b/100, 11070 Belgrade, Serbia; e-mail: zdenkaj@gmail.com

Correspondence to: prim. dr sci. med. Zdenka Janković, Narodnih heroja 41-b/100, 11070 Belgrade, Serbia; e-mail: zdenkaj@gmail.com 